\title{
SEASONAL VARIATION IN HbA1c AND 25(OH) VITAMIN D CONCENTRATIONS IN THE TURKISH POPULATION: COULD RAMADAN BE CHANGING EXPECTATIONS?
}

\author{
TÜRK TOPLUMUNDA HbA1c VE 25(OH)D VITAMINI KONSANTRASYONLARINDAKI \\ MEVSIMSEL DEĞiŞiM: RAMAZAN BEKLENTILERI DEĞişTiRIYOR OLABILIR Mi?
}

\author{
Fulya ÇALIKOĞLU¹ (D), Hülya HACIŞAHINOĞULLARI ${ }^{1}$ (D), Ahmet Faruk KILIÇARSLAN² (D), Reyhan AKAS² (D),

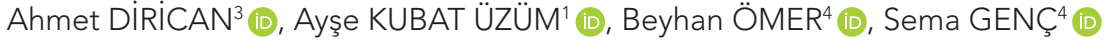

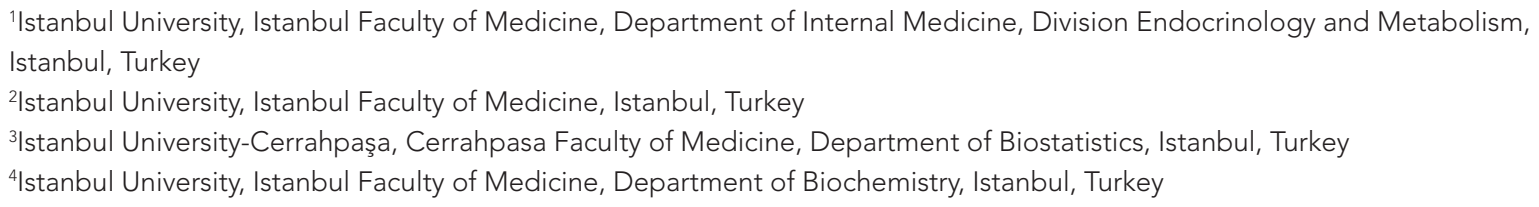

ORCID IDs of the authors: F.Ç. 0000-0002-0964-5142; H.H. 0000-0001-9989-6473; A.F.K. 0000-0001-9565-0169; R.A. 0000-0002-2955-0685; A.D. 0000-0001-8454-4547; A.K.Ü. 0000-0003-0478-1193; B.Ö. 0000-0001-7938-6281; S.G. 0000-0002-2577-9263

Cite this article as: Calikoglu F, Hacisahinogullari $H$, Kilicarslan AF, Akas R, Dirican A, Kubat Uzum A, et al. Seasonal variation in $\mathrm{HbA} 1 \mathrm{c}$ and $25(\mathrm{OH})$ vitamin D concentrations in the Turkish population: could ramadan be changing expectations? J Ist Faculty Med 2022;85(1):117-24. doi: 10.26650/IUITFD.915270

\section{ABSTRACT}

Objective: In this study, the seasonal variations of $\mathrm{HbA} 1 \mathrm{c}$ and serum $25(\mathrm{OH})$ vitamin D were investigated during different seasons in Istanbul.

Materials and Methods: The alterations in $\mathrm{HbA} 1 \mathrm{c}$ and vitamin $D$ were evaluated concerning age and sex. The study consisted of 86,835 samples, selected from the Istanbul Faculty of Medicine Electronic Medical Records.

Results: LC-MS/MS quantified 25(OH)D levels, and $\mathrm{HbA} 1 \mathrm{c}$ were measured in HPLC. The HbA1c level in women was significantly lower than in men $(p<0.001)$, and the $\mathrm{HbA} 1 \mathrm{c}$ level was higher in summer compared with winter $(p<0.001)$ and autumn $(p=0.005)$. The 25(OH)D levels of all groups was $28.2 \pm 15.5 \mathrm{ng} / \mathrm{mL}$ with no difference between men and women. The highest vitamin-D levels were in summer, and the lowest were in winter.

Conclusion: Studies have shown that in both hemispheres of the world, HbA1c levels decrease when the air is warm and increase when the weather is cold. However, contrary to expectations, we witnessed that $\mathrm{HbA} 1 \mathrm{c}$ wa s $0.3 \%$ higher in summer than in winter in Istanbul, where the temperature change over a year is $22.5^{\circ} \mathrm{C}$, the coldest month is January, and the hottest month is August. A possible explanation of our findings could stem from the occurrence of Ramadan in the summer months between

\section{ÖZET}

Amaç: Bu çalışmada İstanbul'da farklı mevsimlerde HbA1c ve serum 25(OH) vitamin D'nin mevsimsel değişimleri araştırılmıştır.

Gereç ve Yöntem: Çalışmada kullanılan 86.835 örnek, İstanbul Tıp Fakültesi Elektronik Tıp Kayıtlarından seçilmiştir. HbA1c ve vitamin D düzeyindeki değişiklikler yaş ve cinsiyete göre değerlendirilmiştir. 25(OH)D seviyeleri LC-MS/MS, HbA1c ise HPLC yöntemleriyle ölçülmüştür.

Bulgular: HbA1c düzeyi kadınlarda erkeklere göre anlamIı olarak düşük $(p<0,001)$ ve yaz aylarında, kış $(p<0,001)$ ve sonbahar $(p=0,005)$ ayları ile karşılaştırıldığında daha yüksek bulunmuştur. $25(\mathrm{OH}) \mathrm{D}$ ortalaması $28,2 \pm 15,5 \mathrm{ng} / \mathrm{mL}$ olup, erkekler ve kadınlar arasında fark bulunmamıştır. En yüksek $D$ vitamini seviyelerinin yaz aylarında, en düşük ise kış aylarında olduğu görülmüştür.

Sonuç: Çalışmalar, dünyanın her iki yarım küresinde de hava ısındığında HbA1c seviyelerinin azaldığını, hava soğuk olduğunda ise arttığını göstermektedir. Ancak bir yıl içinde sıcaklık değişimi$\operatorname{nin} 22,5^{\circ} \mathrm{C}$ olduğu, en soğuk ayın Ocak, en sıcak ayın ise Ağustos olduğu İstanbul'da HbA1c'nin beklenenin aksine yaz aylarında kış aylarına göre \%0,3 daha yüksek olduğu görüldü. Bu durumun, 2015-2017 arasındaki yaz aylarında Ramazan ayının varlığından kaynaklanıyor olabileceği düşünüldü. Öte yandan HbA1c ile

Corresponding author/iletişim kurulacak yazar: bfulyacalikoglu@gmail.com

Submitted/Başvuru: 13.04.2021 • Revision Requested/Revizyon Talebi: 07.05.2021 •

Last Revision Received/Son Revizyon: 11.06.2021 • Accepted/Kabul: 06.07.2021 • Published Online/Online Yayın: 17.01.2022 
2015-2017. However, variations between $\mathrm{HbA} 1 \mathrm{c}$ and 25(OH)D related to temperature changes during the year and age groups were detected.

Keywords: Diabetes mellitus, vitamin D, seasonal variation, HbA1c, Ramadan
25(OH)D arasında yıl ve yaş gruplarındaki sıcaklık değişimlerine bağlı farklılıklar tespit edildi.

Anahtar Kelimeler: Diabetes mellitus, vitamin D, mevsimsel değişiklikler, HbA1c, Ramazan

\section{INTRODUCTION}

Some metabolic factors and hormones demonstrate circannual patterns depending on seasonal environmental factors (1). Some metabolic changes with seasonal variations are seen in blood pressure, heart rate, and some serum metabolites such as serum lipids, glycated hemoglobin (HbA1c), vitamin D, and hormone levels.

Cold weather and some climate factors have been revealed to induce cyclical, seasonal variations. The body's standard thermoregulatory mechanism functions to preserve a stable internal state to survive, and the hypothalamus maintains this. In winter, the production of hormones such as glucagon, epinephrine, and cortisol levels increase with the effect of the cold temperature, which results in high blood glucose levels $(2,3)$. Recent studies have shown that increased body fat and consequently insulin resistance in winter are associated with high cortisol levels and increased tissue sensitivity of glucocorticoids (4). Several studies reported physiologic responses to cold temperatures $(5,6)$.

The hemoglobin A1c (HbA1c) test is essential for accomplishing adequate glucose monitoring in patients with type 1 or type 2 diabetes and screening tests to diagnose diabetes mellitus. The International Expert Committee and the American Diabetes Association (ADA)'s current diagnostic criteria suggest that $A 1 \mathrm{c}$ levels of $6.5 \%$ are indicative of type 2 diabetes, and a level between 5.7-6.4\% indicates a high risk for progression to diabetes mellitus $(7,8)$. Although $\mathrm{HbA} 1 \mathrm{c}$ has many advantages, such as being highly standardized with low biologic variation, it also shows poor validity with a sensitivity of $44 \%$ and a specificity of $79 \%$ at a diagnostic threshold value (6.5\%) (9-11). However, the ADA recently recommended using repeated blood glucose measurements with the estimated average glucose (eAG) to make the best inference from individual data (12). Studies have shown that new-onset type 1 diabetes is mostly seen in winter in the northern hemisphere with seasonal changes (13). However, such seasonal patterns' significance is unclear due to the multifactorial etiology of diabetes (14). Seasonal changes also affect glycemic control and $\mathrm{HbA} 1 \mathrm{c}$ levels in patients with diabetes. These alterations are associated with geographic regions based on temperature variations and latitudes $(13,15)$.

Vitamin $D$ is an important factor in human metabolism, recently shown to have additional roles in insulin resis- tance, type 2 diabetes, cancer, immune system and cognitive dysfunction, and bone metabolism. Many studies have shown a link between insufficient vitamin D levels and diabetes, hypertension, coronary artery disease, and cancer development (16-19). In recent years, the growing public awareness of vitamin D functions, as well as bone metabolism, has led to increased vitamin D supplementation. Also, seasonal variations of vitamin $D$ concentration depending on latitude, diet, and clothing habits have been investigated in previous studies $(20,21)$. Changes in $\mathrm{HbA} 1 \mathrm{c}$ and $25(\mathrm{OH}) \mathrm{D}$ levels have been reported between seasons or months throughout the year and in both hemispheres (22-24).

In this study, we aimed to evaluate the seasonal variations of $\mathrm{HbA} 1 \mathrm{c}$ and serum $25(\mathrm{OH})$ vitamin $\mathrm{D}$ concentrations during different seasons of the year in Istanbul and assess the alterations in $\mathrm{HbA} 1 \mathrm{c}$ and serum 25(OH)D levels concerning age and sex.

\section{MATERIALS AND METHODS}

\section{Study group}

This study consisted of 86,835 subjects, selected from the Istanbul Faculty of Medicine Clinical Laboratory Electronic Medical Records between September 2015 and February 2018 . The data selected were unidentified and only included age, sex, the month of blood sampling, and $\mathrm{HbA1c}$ and 25(OH)D levels. All subjects who participated in the study were residing in Istanbul (Latitude: North $\left.41^{\circ} 00^{\prime}\right)$.

The blood samples were collected in vacutainer tubes containing dipotassium-EDTA (K2-EDTA) (Becton Dickinson, Plymouth, UK), for $\mathrm{HbA} 1 \mathrm{c}$ and $25(\mathrm{OH}) \mathrm{D}$ assays. The subjects were categorized according their age and sex. According to age, the study group was classified in 6 subgroups: 0-5 years, 6-19 years, 20-39 years, $40-65$ years, 65-80 years, and over 80 years. The study protocol was approved by the Ethical Committee of Istanbul Faculty of Medicine (Date: 29.03.2019, No: 06).

\section{Methods}

$\mathrm{HbA1c}$ levels were measured using cation-exchange high-performance liquid chromatography [HPLC] with Bio-Rad Turbo II (Bio-Rad, Richmond, California, USA) on the same day within four hours of blood sampling. All $\mathrm{HbA} 1 \mathrm{c}$ results are expressed in percentage (\%), using the certified method of the National Glycohemoglobin Standardization Program/Diabetes Control and Compli- 
cations Trial (NGSP/DCCT). The precision results (CVs\%) were $2.5,4.0$, and $2.3 \%$ at normal, high, and intermediate $\mathrm{HbA} 1 \mathrm{c}$ levels, respectively. Based on ADA criteria, A1c levels of $6.5 \%$ were accepted as an indicator of type 2 diabetes and a level between $5.7-6.4 \%$ were accepted as an indicator of a high risk of progression to diabetes mellitus (pre-diabetes) (8).

The collected blood samples for vitamin D measurement were protected from light, centrifuged, and stored at $-80^{\circ} \mathrm{C}$ until studied. $25(\mathrm{OH}) \mathrm{D}$ levels were quantified using the LC-MS/MS method with a Zivak Tandem Gold HPLC unit and a Zivak D2/D3 Tandem GOLD Triple Quadrupole MS/MS unit (Zivak Technologies, Turkey). The precision results (CVs \%) were $7.2 \%$ and $7.3 \%$ at low $(22.4 \pm 3.3 \mathrm{ng} / \mathrm{mL})$ and high levels $(82.3 \pm 11.8 \mathrm{ng} / \mathrm{mL})$, respectively. Vitamin $D$ deficiency is defined as $25(\mathrm{OH}) \mathrm{D}$ levels of below $20 \mathrm{ng} / \mathrm{mL}$ (50 mmol/L) according to the Endocrine Society (25).

The monthly and seasonal mean $\mathrm{HbA} 1 \mathrm{c}$ and $25(\mathrm{OH}) \mathrm{D}$ levels for the entire study group were calculated using a maximum of one and half years' data, and evaluated for subgroups depending on age groups, sex, and temperature differences.

The mean monthly temperatures for different months were obtained from available meteorological information for Istanbul.

\section{Statistical interpretation}

The statistical analysis was performed using the SPSS 15 software program (SPSS, Chicago, IL, USA). A p value of $<0.05$ was considered statistically significant. The differences among multiple subgroups were determined using one-way analysis of variance (ANOVA) or the Kruskal-Wallis test with post-hoc analysis. Multivariate logistic regression analysis was performed to determine the independent variables that were associated with Vitamin $\mathrm{D}$ and $\mathrm{HbA} 1 \mathrm{c}$.

\section{RESULTS}

The study comprised of 86,835 subjects $(58.5 \%$ women, $40.5 \%$ men). The participants' mean age was $39.4 \pm 23.2$ (range, 1-84) years. The women were slightly older than the men $(40.1 \pm 21$ years vs. $38.5 \pm 24.3$ years, respectively). Of the study group, $12 \%(n=12243)$ were less than 5 years of age; $13 \%(n=12540)$ were aged $6-19$ years; $21 \%$ $(n=20568)$ were aged $20-39$ years; $41 \%(n=39684)$ were aged $40-65$ years, $11 \%(n=1800)$ were aged $65-80$ years, and $2 \%$ were over 80 years of age.

The mean $\mathrm{HbA} 1 \mathrm{c}$ concentration of all participants was $6.53 \pm 1.8 \%$. The women's HbA1c levels were significantly lower than in men $(6.42 \pm 1.8 \%$ vs. $6.64 \pm 1.8 \% ; p<0.001)$ (Table 1).

Istanbul's average temperature obtained from available meteorologic information was the lowest in January $\left(+4.0^{\circ} \mathrm{C}\right)$, and the highest in August $\left(26.6^{\circ} \mathrm{C}\right)$. The $\mathrm{HbA} 1 \mathrm{C}$ levels varied significantly across the different seasons. The average $\mathrm{HbA1c}$ level was higher in summer compared with winter $(6.66 \pm 1.9 \%$ vs. $6.53 \pm 1.9 \% ; p<0.001)$ and autumn (6.52 $\pm 1.7 \% ; p=0.005)$. The HbA1c levels in winter were also significantly different compared with spring ( $p=0.003)$. The monthly variations in $\mathrm{HbA} 1 \mathrm{c}$ levels showed a peak in June and July, and lowered following October. Significant differences were obtained between January and June, July and August $(p<0.001)$, and also between February and August $(p<0.001)$ (Figure 1A).

When we investigated $\mathrm{HbA} 1 \mathrm{c}$ levels according to the age groups, the $\mathrm{HbA} 1 \mathrm{c}$ levels of the subjects aged $0-5$

Table 1: $\mathrm{HbA} 1 \mathrm{c}$ and $25(\mathrm{OH})$ vitamin $\mathrm{D}$ levels between sex and age subgroups

\begin{tabular}{|c|c|c|c|c|}
\hline & $\begin{array}{l}\text { Mean age } \\
\text { (years } \pm S D \text { ) }\end{array}$ & $\begin{array}{c}\text { Sex distribution } \\
(\%)\end{array}$ & $\begin{array}{l}\mathrm{HbA1c} \\
(\%)\end{array}$ & $\begin{array}{c}\text { 25(OH) Vitamin D } \\
(\mathrm{ng} / \mathrm{mL})\end{array}$ \\
\hline Women & $41.1 \pm 21.0$ & 58.5 & $6.42 \pm 1.80^{x}$ & $27.4 \pm 20.2$ \\
\hline Men & $38.5 \pm 24.3$ & 40.5 & $6.64 \pm 1.80^{x}$ & $27.5 \pm 15.9$ \\
\hline Age groups & $\begin{array}{l}\text { Mean age } \\
\text { (years } \pm S D)\end{array}$ & $\begin{array}{c}\text { Age groups } \\
\text { distributions (\%) }\end{array}$ & $\begin{array}{l}\mathrm{HbA1c} \\
(\%)\end{array}$ & $\begin{array}{c}25(\mathrm{OH}) \text { Vitamin } D \\
(\mathrm{ng} / \mathrm{mL})\end{array}$ \\
\hline $0-5$ years & $2.71 \pm 1.5$ & 12 & $5.99 \pm 1.5^{a, b, c}$ & $32.3 \pm 17.1^{a, b}$ \\
\hline 6-19 years & $11.4 \pm 4.2$ & 13 & $6.29 \pm 2.2^{a, b, c}$ & $24.8 \pm 14.6^{c, d}$ \\
\hline 20-39 years & $30.3 \pm 5.9$ & 21 & $5.70 \pm 1.1^{a, b, c}$ & $24.43 \pm 19.7^{a, b, c}$ \\
\hline 40-65 years & $52.7 \pm 7.1$ & 41 & $6.80 \pm 1.9$ & $27.00 \pm 18.8^{d}$ \\
\hline $66-80$ years & $71.3 \pm 4.02$ & 11 & $6.71 \pm 1.8$ & $28.83 \pm 19.6^{d}$ \\
\hline$>80$ years & $84.0 \pm 3.5$ & 2 & $6.44 \pm 1.3$ & $30.30 \pm 23.1$ \\
\hline
\end{tabular}

x: $p<0.001$ : intergroup analysis, ${ }^{a}: p<0.001$ : in comparison with group 3 (aged 40-65), b: $p<0.001$ : in comparison with group 4 (aged 65-80),

c: $p>0.001$ : in comparison with group 5 (aged $>80$ years), $d: p<0.001$ 


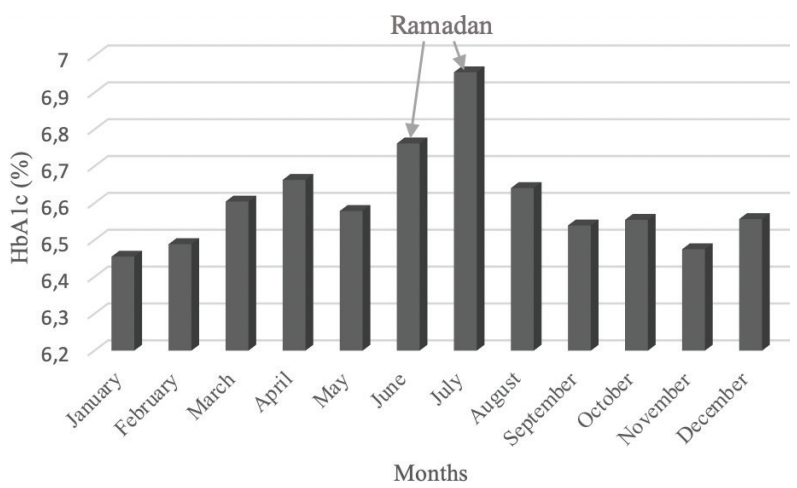

Figure 1(A): Alteration in $\mathrm{HbA} 1 \mathrm{c}$ percentages in respect to months

years and 20-39 years and were lower compared with subjects older than 40 years $(40-65 ; 65-80$ and $>80$ years; $p<0.001, p<0.001$ and $p=0.003$, respectively). The mean $\mathrm{HbA} 1 \mathrm{c}$ levels in those aged $40-65$ and $65-80$ were also higher than in subjects aged over 80 . $\mathrm{HbA} 1 \mathrm{c}$ levels between sex and age subgroups are presented in Table 1.

The mean 25(OH)D levels of all participants was $28.2 \pm 15.5 \mathrm{ng} / \mathrm{mL}$. No significant difference was obtained between the mean levels $25(\mathrm{OH}) \mathrm{D}$ of men and women $(27.5 \pm 15.9 \mathrm{ng} / \mathrm{mL}, 27.4 \pm 20.2 \mathrm{ng} / \mathrm{mL}$, respectively) (Table 1). When the vitamin $D$ levels were evaluated across dif- ferent seasons, all groups' highest vitamin D levels were in summer. The lowest was in winter with a difference of $6.5 \mathrm{ng} / \mathrm{mL}(30.98 \pm 12.7$ vs. $24.48 \pm 17.8 \mathrm{ng} / \mathrm{mL}, \mathrm{p}<0.001)$. The mean 25(OH)D levels were also higher in summer compared with autumn and spring $(29.8 \pm 17.9 \mathrm{ng} / \mathrm{mL}$, $26.9 \pm 21.0 \mathrm{ng} / \mathrm{mL}$, respectively; $p<0.001$, for both) (Table 2). The monthly alterations in $25(\mathrm{OH}) \mathrm{D}$ levels demonstrated a peak in August (34\% increase) through January to August, and tended to decline following October. Significant differences were found between vitamin $D$ levels of January and July/August ( $p<0.001$ for both), and also between December and August, and September $(p<0.001$, for both) (Figure 1B). Average monthly 25(OH)D levels are presented in Figure 1(B).

When we compared $25(\mathrm{OH}) \mathrm{D}$ levels according to the age groups, the groups aged 6-19 and 20-39 years were the lowest among all age groups. The mean $25(\mathrm{OH}) \mathrm{D}$ concentrations of individuals in these groups were significantly lower than those aged $0-5$ years, $40-65$ years, and $65-80$ years $(p<0.001$ and $p<0.001)$ (Figure $2 B)($ Table 1$)$.

The prevalence of vitamin $D$ deficiency for all participants was $42.4 \%$ : $41.4 \%$ for men and $44.5 \%$ for women.

Factors associated with the risk of 25(OH)D deficiency and the risk of prediabetes and diabetes mellitus were evaluated using multiple logistic regression models. Age, sex, and some months were associated with increased

Table 2: Mean HbA1c and 25(OH) vitamin D levels and average temperatures for Istanbul in different seasons

\begin{tabular}{lccc}
\hline Seasons & $\begin{array}{c}\text { Mean temperature } \\
\left({ }^{\circ} \mathrm{C}\right)\end{array}$ & $\begin{array}{c}\text { HbA1c } \\
(\%)\end{array}$ & $\begin{array}{c}\mathbf{2 5 ( O H )} \text { Vitamin D } \\
(\mathbf{n g} / \mathbf{m L})\end{array}$ \\
Spring & 15.1 & $6.61 \pm 1.9$ & $26.9 \pm 21.0^{\mathrm{c}}$ \\
Summer & 25.7 & $6.66 \pm 1.9^{\mathrm{a}, \mathrm{b}}$ & $30.98 \pm 12.7^{\mathrm{a}}$ \\
Autumn & 18.5 & $6.52 \pm 1.7$ & $29.8 \pm 17.9^{\mathrm{a}}$ \\
Winter & 6.98 & $6.53 \pm 1.9$ & $24.5 \pm 17.8$ \\
\hline
\end{tabular}

a: $p<0.001$ : in comparison with winter, ${ }^{b}: p<0.01$ : in comparison with autumn, $c$ : $p<0.001$ : in comparison with summer

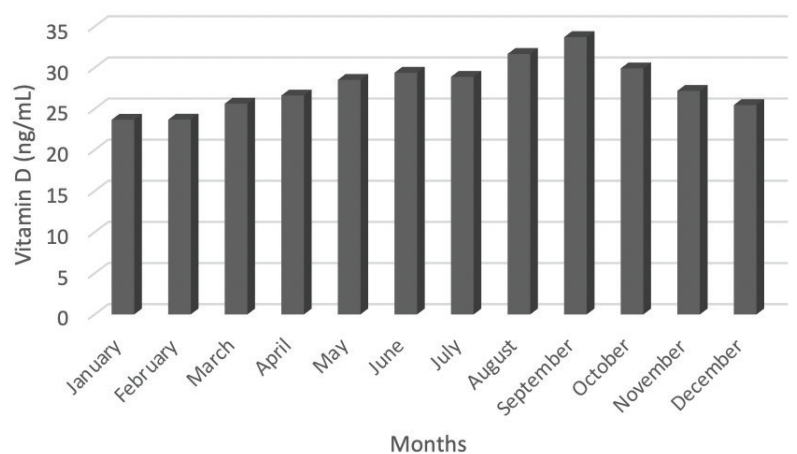

Figure 1(B): Alteration in $25(\mathrm{OH})$ vitamin $\mathrm{D}$ concentrations in respect to months

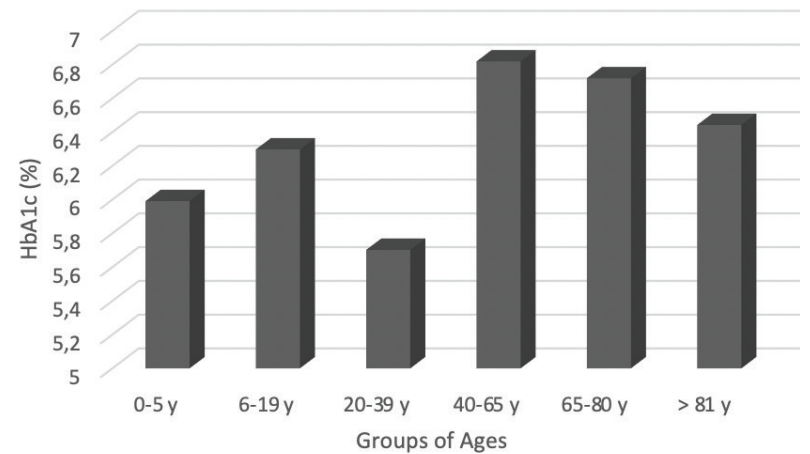

Figure 2(A): Alteration in $\mathrm{HbA1c}$ percentages in respect to age groups 


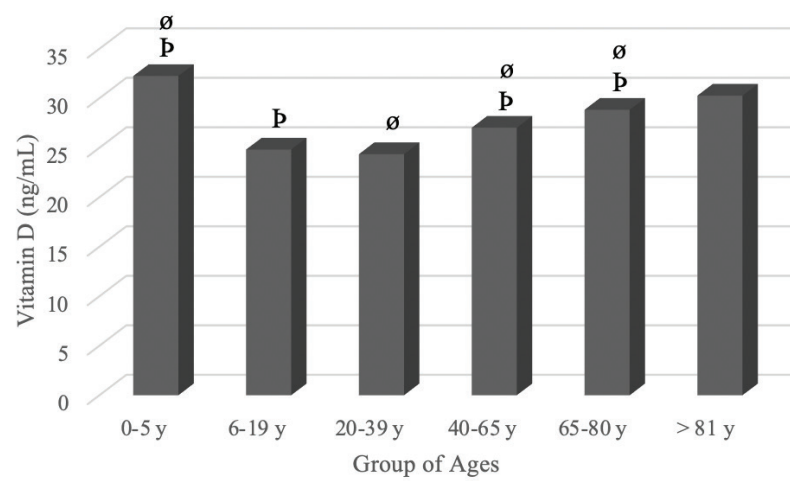

Figure 2(B): Alteration in 25(OH)vitamin D concentrations in respect to age groups

P: Differences between group 6-19y to 0-5y, 40-65y and 65-80y; $\mathrm{p}<0.001$

ø: Differences between group 20-30y to $0-5 y, 40-65 y$ and $65-80 y$; $p<0.001$

HbA1c concentration (the results were not shared). In women, an increase in $\mathrm{HbA} 1 \mathrm{c}$ levels was associated with a higher risk in the prevalence of diabetes than in men ( $p=0.002$ in women, $p=0.021$ in men). The months April and May seemed to be associated with an increase in $\mathrm{HbA} 1 \mathrm{c}$ levels ( $\mathrm{p}=0.005$ and $\mathrm{p}=0.002$, respectively).

Age, certain months (February, March), and Ramadan (Jun 6 to July 4, 2016) were determined as associated with vitamin $D$ deficiency $(p<0.001, p=0.025, p=0.009$, and $p=0.004$, respectively). Also, an association was found between seasonal temperature change and $25(\mathrm{OH}) \mathrm{D}$ levels $(r=0.184, p<0.001)$.

\section{DISCUSSION}

Studies have shown that in both hemispheres of the world, HbA1c levels decrease when the air is warm and increase when the weather is cold. This situation has been associated with an increase in dietary energy and decreased physical activity during the winter months in most of the studies. In fact, in studies conducted in different geographies, it has been observed that the $\mathrm{HbA} 1 \mathrm{c}$ values are even lower in the colder winter months (23, $24,26,27)$. However, contrary to expectations, we have seen that $\mathrm{HbA} 1 \mathrm{c}$ is $0.3 \%$ higher in summer than in winter in Istanbul, where the temperature change over a year is $22.5^{\circ} \mathrm{C}$, the coldest month is January, and the hottest month is August. Tseng et al. reported that the temperature differences were around $25^{\circ} \mathrm{C}$ for East Orange, New Jersey in the United States of America, with a difference in $\mathrm{HbA} 1 \mathrm{c}$ values of $0.22 \%$, in accordance with our findings (24). They also suggested that seasonal variations in $\mathrm{HbA} 1 \mathrm{c}$ levels were greater where the temperature differences were larger (24). For example, seasonal variation was not observed in a study conducted in a tropical country with no significant temperature differences (30).

A possible explanation of our findings could stem from the presence of Ramadan in the summer months between 2015-2017, which requires fasting from dawn to sunset, and may cause a change of dietary habits and frequency in people who are fasting. Consuming a high calorie diet depending on the long fasting period may cause high glucose and increased $\mathrm{HbA} 1 \mathrm{c}$ levels. The loss of circadian rhythm and increased evening cortisol levels have been reported to cause detrimental effects on metabolic regulation during Ramadan (28). According to our data, the peak of HbA1c seen in July can be explained by the fact that the fasting periods for Ramadan were in June for both years and $50 \%$ of the $\mathrm{HbA} 1 \mathrm{c}$ reflects the average glucose level over the last 30 days in a threemonth period (29). Additionally, it is also inevitable that people who fast do less physical activity because of the low energy intake during the whole day.

When we tested the HbA1c levels according to sex and age groups, the HbA1c levels in women were significantly lower than in men. The mean $\mathrm{HbA} 1 \mathrm{c}$ levels in subjects aged 40-65 and 65-80 were higher than in subjects aged under 40 years and over 80 years. These findings are consistent with the previous studies' results $(15,26)$. When the $\mathrm{HbA} 1 \mathrm{c}$ levels were controlled with logistic regression models, the months depending on the temperature differences remained associated with increases in $\mathrm{HbA} 1 \mathrm{c}$. Women also had a higher risk than men related to the increased $\mathrm{HbA} 1 \mathrm{c}$ values. Aging is another known factor associated with the higher $\mathrm{HbA} 1 \mathrm{c}$-associated increased prevalence of prediabetes and diabetes mellitus. In our cross-sectional population-based study performed in urban and rural parts of Turkey, the prevalence of prediabetes and diabetes was $8.2 \%$ and $16.5 \%$, respectively, higher in women than in men. We also found an association between increasing age and the prevalence of diabetes in both sexes (31).

In recent years, several studies have investigated the relation between serum 25(OH)D and glucose homeostasis $(32,33)$. We obtained the highest vitamin D levels in August and September and the lowest in January and February, with a difference of $6.5 \mathrm{ng} / \mathrm{mL}$ between summer and winter, which is consistent with other studies (34-36). The 25(OH)D level of summer was also higher than autumn and spring. Nevertheless, studies show no seasonal differences in vitamin $D$ levels associated with the sunny season $(22,37)$. When we tested changes in vitamin $D$ levels over the months, we found that the highest vitamin D levels from January to August were in August (a 34\% increase from January). They tended to decline following October, presenting significant differences between January with July and August. However, studies have sug- 
gested that seasonal temperature changes are not the only reason for alterations in vitamin $\mathrm{D}$ concentrations. Aging, body mass index/body fat percentage, calcium intake, genetics, dietary fat content, some diseases, and some medications are other factors that affect levels of $25(\mathrm{OH}) \mathrm{D}(38,39)$

According to our results, $42.4 \%$ of our study group had vitamin D deficiency (41.4\% for men and $44.5 \%$ for women). Similar or higher deficiency rates were reported by other studies $(22,31,40)$. It has been reported that vitamin D deficiency is more prevalent in certain regions of the $\mathrm{w}$ orld (41). In the current study, 25(OH)D levels were lower in subjects aged 0-5 years than over 40 years. Heidari et al. also reported higher vitamin $D$ levels for subjects aged over 60 years and lower levels for those younger than 30 years, in accordance with our findings (22). When we controlled the $25(\mathrm{OH}) \mathrm{D}$ levels with multivariate logistic regression models, the effect of age, month (February, March), and Ramadan remained significant. According to our data, the lowest vitamin D levels were between January and March. Zho et al. reported a significant effect of seasons on 25(OH)D levels by logistic regression analysis (42). Also, the significant association of temperature in a year with $25(\mathrm{OH}) \mathrm{D}$ concentrations supports the importance of a sunny climate in synthesizing vitamin D (41). Several studies have revealed that the generation of $25(\mathrm{OH}) \mathrm{D}$ is decreased with aging and skin pigmentation $(18,43,44)$. Although the subjects had higher vitamin D levels between $40-65$ years than at younger ages, significantly lower vitamin $D$ levels were obtained from subjects above 80 years compared with middle ages. These findings also indicate that the skin's ability to synthesize vitamin $\mathrm{D}$ decreases with older age. The fact that the average $25(\mathrm{OH}) \mathrm{D}$ levels were not significantly different in both sexes could be due to our study group's characteristics. Our study group consisted of subjects selected from our electronic medical records. Accordingly, we had no information about their dietary habits, diseases such as tuberculosis, diabetes, therapeutic drugs, including vitamin $\mathrm{D}$ and/or oral antidiabetics, and the lack of other biochemical parameters supporting vitamin D deficiency or serum glucose levels. Therefore, other potentially confounding factors could not be evaluated, which is the major limitation of our study.

Our study has shown that although many studies concretely reveal the close relationship between changes in air temperature, $\mathrm{HbA} 1 \mathrm{c}$, and $25(\mathrm{OH}) \mathrm{D}$, the changes in physiological and human habits caused by Ramadan can change what is known. However, our study could not determine how many subjects fasted, received vitamin D replacement, had diabetes or a disease that could affect sugar regulation, or used drugs that could cause an increase in blood sugar. Therefore, further studies are needed to investigate the effects of dietary habits, exercise, and chronic diseases on $\mathrm{HbA} 1 \mathrm{c}$ and vitamin D levels.

Note: The editor in chief was not involved in the evaluation, peer-review and decision processes of the article, and these processes were carried out by the associate editors.

Ethics Committee Approval: This study was approved by the Clinical Research Ethical Committee of the Istanbul University, Istanbul Faculty of Medicine (Date: 29.03.2019, No: 06).

Peer Review: Externally peer-reviewed.

Author Contributions: Conception/Design of Study- S.G., B.Ö., A.K.Ü., F.Ç.; Data Acquisition- H.H., F.Ç., A.F.K., R.A.; Data Analysis/Interpretation- A.D., S.G., A.K.Ü., F.Ç.; Drafting ManuscriptS.G., A.K.Ü., F.Ç., H.H.; Critical Revision of Manuscript- S.G., B.Ö., A.K.Ü., F.Ç.; Approval and Accountability- F.Ç., H.H., A.F.K., R.A., A.D., A.K.Ü., B.Ö., S.G.

Conflict of Interest: Authors declared no conflict of interest

Financial Disclosure: Authors declared no financial support.

\section{REFERENCES}

1. Mavri A, Guzic-Salobir B, Salobir-Pajnic B, Stare J, Stegnar M. Seasonal variation of some metabolic and haemostatic risk factors in subjects with or without coronary artery disease. Blood Coagul Fibrinolysis 2001;12(5):359-65. [CrossRef]

2. Kristal-Boneh E, Froom P, Harari G, Malik M, Ribak J. Summer-winter differences in $24 \mathrm{~h}$ variability in heart rate. J Cardiovasc Risk 2000;7(2):141-6. [CrossRef]

3. Woodhouse PR, Khaw KT, Plummer M. Seasonal variation of blood pressure and its relationship to ambient temperature in an elderly population. J Hypertens 1993;11(11):1267-74. [CrossRef]

4. Hansen AM, Garde AH, Skovgaard LT, Christensen JM. Seasonal and biological variation of urinary epinephrine, norepinephrine, and cortisol in healthy women. Clin Chim Acta 2001;309(1):25-35. [CrossRef]

5. Näyhä S. Cold and risk of cardiovascular diseases. A review. Int J Circumpolar Health 2002;61(4):373-80. [CrossRef]

6. Nagarajan V, Fonarow GC, Ju C, Pencina M, Laskey WK, Maddox TM, Hernandez A, et al. Seasonal and circadian variations of acute myocardial infarction: Findings from the Get with The Guidelines-Coronary Artery Disease (GWTGCAD) program. Am Heart J 2017;189:85-93. [CrossRef]

7. David MN. International Expert Committee report on the role of the HbA1c assay in the diagnosis of diabetes. Diabetes Care 2009;32(7):1327-34. [CrossRef]

8. American Diabetes Association. Diagnosis and Classification of Diabetes Mellitus. Diabetes Care 2010;33(Suppl 1):S6269. [CrossRef]

9. Rohlfing C, Wiedmeyer HM, Little R, Grotz VL, Tennill A, England J, et al. Biological variation of glycohemoglobin. Clin Chem 2002;48(7):1116-8. [CrossRef]

10. Kilpatrick ES, Bloomgarden ZT, Zimmet PZ. Is haemoglobin A1C a step forward for diagnosing diabetes? BMJ 2009;339:b4432. [CrossRef] 
11. Malkani S, Mordes JP. Implications of using Hemoglobin A1c for diagnosing diabetes mellitus. Am J Med 2011;124(5):395- 401. [CrossRef]

12. American Diabetes Association. Classification and Diagnosis of Diabetes. Diabetes Care 2016;39(Suppl 1):S1322. [CrossRef]

13. Moltchanova EV, Schreier N, Lammi N, Karvonen M. Seasonal variation of diagnosis of Type 1 diabetes mellitus in children worldwide. Diabet Med 2009;26(7):673-8. [CrossRef]

14. Eisenbarth GS. Type I diabetes mellitus. A chronic autoimmune disease. N Engl J Med 1986;314(21):1360-8. [CrossRef]

15. Zhang L, Weiyi L, Xian T, Pan Q, Li M, Guo L. Seasonal variations of hemoglobin A1c in residents of Beijing, China Int J Clin Exp Pathol 2016;9(9):9429-35.

16. Holick MF. High prevalence of vitamin D inadequacy and implications for health. Mayo Clin Proc 2006;81:353-73. [CrossRef]

17. El Baba K, Zantout MS, Akel R, Azar ST. Seasonal variation of vitamin $\mathrm{D}$ and $\mathrm{HbA} 1 \mathrm{c}$ levels in patients with type 1 diabetes mellitus. In the Middle East. Int J Gen Med 2011;4:635-8. [CrossRef]

18. Pilz S, Kienreich K, Stückler D, Meinitzer A, Tomaschitz A. Associations of sun exposure with 25-hydroxyvitamin D and parathormone levels in a cohort of hypertensive patients: The Graz Endocrine causes of hypertension (GECOH) Study. Int J Endocrinol 2012;2012:732636. [CrossRef]

19. Heidari B, Shirvani JS, Firouzjahi A, Heidari P, Hajian-Tilaki KO. Association between nonspecific skeletal pain and vitamin D deficiency. Int J Rheum Dis 2010;13:340-6. [CrossRef]

20. Lips P. Worldwide status of vitamin D nutrition. J Steroid Biochem Mol Biol 2010;121(1-2):297-300. [CrossRef]

21. Genc S, Omer B, Aycan-Ustyol E, Kumral A, Gurdol F. Bone Turnover Markers and Vitamin D Status in Postmenopausal Turkish Women Int J Vitam Nutr Res 2012;82(1):27-33. [CrossRef]

22. Heidari B, Haji Mirghassemi MB. Seasonal variations in serum vitamin D according to age and sex. Caspian J Inter Med 2012;3(4):535-40.

23. Higgins $T$, Saw S, Sikaris K, Wiley CL, Cembrowski GC, Lyon AW, et al. Seasonal variation in Hemoglobin A1c:Is it the same in both hemispheres? J Diabetes Sci Technol 2009;3(4):668-71. [CrossRef]

24. Tseng CL, Brimacombe M, Xie M, Rajan M, Wang H, Kolassa $J$, et al. Seasonal patterns in monthly Hemoglobin A1c values. Am J Epidemiol. 2005;161(6):565-74. [CrossRef]

25. Holick MF, Binkley NC, Bischoff-Ferrari HA, Gordon CM, Hanley DA, Heaney RP, et al. Evaluation, treatment, and prevention of vitamin $D$ deficiency: An endocrine society clinical practice guideline. J Clin Endocrinol Metab 2011;96:1911-30. [CrossRef]

26. Pereira MTR, Lira D, Bacelar C, Oliveira JC, Carvalho AC. Seasonal variation of haemoglobin A1c in a Portugal adult population. Arch Endocrinol Metab 2015;59:231-5. [CrossRef]

27. Ryu OH, Lee S, Yoo HJ, Choi MG. Seasonal variations in glycemic control of type 2 diabetes in Korean women. J Endocrinol Invest 2014;37:575-81. [CrossRef]

28. Bahijri SM, Ajabnoor GM, Borai A, Al-Aama JY, Chrousos GP. Effect of Ramadan fasting in Saudi Arabia on serum bone profile and immunoglobulins. Ther Adv Endocrinol Metab 2015;6(5):223-2. [CrossRef]
29. Boutayeb W, Boutayeb A, Lamlili M, Ben El Mostafa $\mathrm{S}$, Zitouni N. Simulation of a computed $\mathrm{HbA1c}$ using a weighted average glucose. SpringerPlus 2016;5:226. [CrossRef]

30. Hawkins RC. Circannual variation in glycohemoglobin in Singapore. Clin Chim Acta 2010;411(1-2):18-21. [CrossRef]

31. Satman I, Omer B, Tutuncu Y, Kalaca S, Gedik S, Dinccag N, et al. Twelve-year trends in the prevalence and risk factors of diabetes and prediabetes in Turkish adults. Eur J Epidemiol 2013;28(2):169-80. [CrossRef]

32. Mitri J, Dawson-Hughes B, Hu FB, Pittas AG. Effects of vitamin $D$ and calcium supplementation on pancreatic beta cell function, insulin sensitivity and glycemia in adults at high risk of diabetes: The calcium and vitamin $D$ for Diabetes Mellitus (CaDDM) randomized controlled trial. Am J Clin Nutr 2011;94(2):486-94. [CrossRef]

33. Kayanil S, Vieth R, Retnakaran R, Knight JA, Qi Y, Gerstein $H C$, et al. Association of vitamin $D$ and insulin resistance and beta-cell dysfunction in subjects at risk for type 2 diabetes. Diabetes Care 2010;33(6):1379-81. [CrossRef]

34. Bird ML, Hill KD, Robertson IK, Ball MJ, Pittaway J, Williams AD. Serum (25(OH)D) status, ankle strength, and activity show seasonal variation in older adults: relevance for winter falls in higher latitudes. Age Ageing 2013;42(2):181-5. [CrossRef]

35. Rockell JE, Skeaff CM, Venn BJ, Williams SM, Green TJ. Vitamin D insufficiency in New Zealanders during winter is associated with higher parathyroid hormone concentrations: Implications for bone health? N Z Med J 2008;121(1286)75-84.

36. Shoben AB, Kestenbaum B, Levin G, Hoofnagle AN, Psaty BM, Siscovick DS, et al. Seasonal variation in 25-hydroxyvitamin $D$ concentrations in the cardiovascular health study. Am J Epidemiol 2011;174(12):1363-72. [CrossRef]

37. Cong E, Walker MD, Kepley A, Zhang C, McMahon DJ, Silverberg SJ. Seasonal variability in Vitamin D levels no longer detectable in primary hyperparathyroidism. J Clin Endocrinol Metab 2015;100(9);3452-9. [CrossRef]

38. Sohmiya, M, Kanazawa, I, Kato, Y. Seasonal changes in body composition and blood $\mathrm{HbA} 1 \mathrm{c}$ levels without weight change in male patients with type 2 diabetes treated with insulin. Diabetes Care 2004;27(5):1238-9. [CrossRef]

39. Shea MK, Houston DK, Tooze JA, Davis CC, Johnson MA, Hausman DB, et al. Correlates and prevalence of insufficient 25-hydroxyvitamin D status in black and white older adults: the health, aging, and body composition study. J Am Geriatr Soc 2011;59(7):1165-74. [CrossRef]

40. Buhary BM, Almohareb O, Aljohani N, Alrajhi S, Elkaissi S, Sherbeeni $S$, et al. Association of glycosylated hemoglobin levels with vitamin D status. J Clin Med Res 2017;9(12):101318. [CrossRef]

41. Van Schoor NM, Lips P. Worldwide vitamin D status. Best Pract Res Clin Endocrinol Metab 2011;25(4):671-80. [CrossRef]

42. Zhao LJ, Zhou Y, Bu F, Travers-Gustafson D, Ye A, Xu X, et al. Factors predicting vitamin $D$ response variation in nonHispanic white postmenopausal women. J Clin Endocrinol Metab 2012;97(8):2699-705. [CrossRef] 
42. Melin A, Wilske J, Ringertz H, Saaf M. Seasonal variations in serum levels of 25-hydroxyvitamin $D$ and parathyroid hormone but no detectable change in femoral neck bone density in an older population with regular outdoor exposure. J Am Geriatr Soc 2001;49(9):1190-6. [CrossRef]
43. Bikle DD. Vitamin D and the skin: Physiology and pathophysiology. Rev Endocr Metab Disord 2012;13(1):319. [CrossRef]

44. Perez-Lopez FR, Chedeauni P, Fernandez-Alonso AM. Vitamin D and aging: beyond calcium and bone metabolism. Maturitas 2011;69(1):27-36. [CrossRef] 